NOTICE

PORTIONS OF THIS REPORT ARE ILLEGIBLE.II

has been reproduced rodest possible avail-

LA- -10067-MS

ability.

\title{
Well Log Interpretation of Certain Geothermal Fields in the Imperial Valley, California
}

DE84 013853

\author{
Iraj Ershaghi*
}

Doddy Abdassah*

\section{DISCLAIMER}

This report was prepared as an account of work sponsored by an agency of the United States Government. Neither the United States Government nor any agency thereof, nor any of their employees, makes any warranty, express or implied, or assumes any legal liability or responsibility for the accuracy, completeness, or usefulness of any information, apparatus, product, or process disclosed, or represents that its use would not infringe privately owned rights. Reference herein to any specific commercial product, process, or service by trade name, trademark, manufacturer, or otherwise does not necessarily constitute or imply its endorsement, recommendation, or favoring by the United States Government or any agency thereof. The views and opinions of authors expressed herein do not necessarily state or reflect those of the United States Government or any agency thereof.

Department of Petroleum Engineering, University of Southern California, University Park, Los Angeles, CA 90089. 


\section{DISCLAIMER}

This report was prepared as an account of work sponsored by an agency of the United States Government. Neither the United States Government nor any agency Thereof, nor any of their employees, makes any warranty, express or implied, or assumes any legal liability or responsibility for the accuracy, completeness, or usefulness of any information, apparatus, product, or process disclosed, or represents that its use would not infringe privately owned rights. Reference herein to any specific commercial product, process, or service by trade name, trademark, manufacturer, or otherwise does not necessarily constitute or imply its endorsement, recommendation, or favoring by the United States Government or any agency thereof. The views and opinions of authors expressed herein do not necessarily state or reflect those of the United States Government or any agency thereof. 


\section{DISCLAIMER}

Portions of this document may be illegible in electronic image products. Images are produced from the best available original document. 
CONTENTS

ABBREVIATIONS AND SYMBOLS .................... vi vi

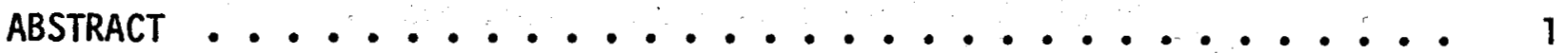

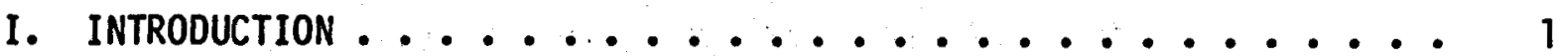

II. HYDROTHERMAL GEOTHERMAL FIELDS IN THE IMPERIAL VALLEY . . . . 2

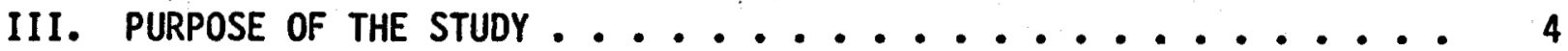

IV. METHOD OF STUDY . . . . . . . . . . . . . . 5

V. REVIEW OF LOG-DERIVED PARAMETERS ............... 6

VI. ANALYSIS OF WELL LOG DATA ................ 6

VII. EFFECT OF PYRITE CONTENT AND FRACTURES . . . . . . . . . 18

VIII. SUMMARY AND CONCLUSIONS ................. 20

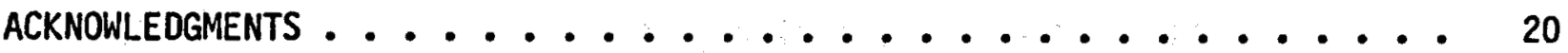

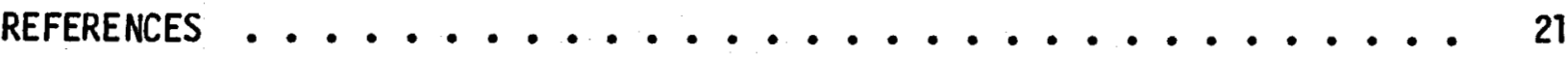

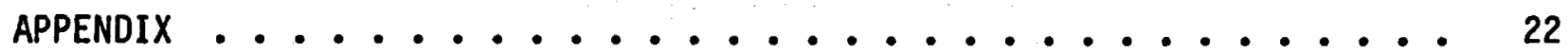

v 


\section{ABBREVIATIONS AND SYMBOLS}

CNFD

$c_{0}$

$c_{w}$

DIL

F

$Q_{v}$

${ }_{\text {ILD }}$

$R_{L L 8}$

$R_{\text {mf }}$

$R_{W}$

SP

${ }^{\phi} \mathrm{D}$

$\phi_{N}$

$p_{b}$

Compensated neutron/formation density

Conductivity of brine-saturated rock, mho $\mathrm{cm}^{-1}$

Conductivity of formation brine, mho $\mathrm{cm}^{-1}$

Dual induction Laterolog

Formation resistivity factor

Cation exchange capacity per unit volume, meq/me

Resistivity from deep induction $10 \mathrm{~g}, \Omega \mathrm{m}$

Resistivity from Laterolog $8, \Omega \mathrm{m}$

Mud filtrate resistivity, $\Omega \mathrm{m}$

Formation water resistivity, $\Omega \mathrm{m}$

Spontaneous potential, mV

Density porosity, fraction

Neutron porosity, fraction

Bulk density, $\mathrm{g} / \mathrm{cm}^{3}$ 
WELL LOG INTERPRETATION OF CERTAIN GEOTHERMAL FIELDS

IN THE IMPERIAL VALLEY, CALIFORNIA

by

Iraj Ershaghi and Doddy Abdassah

\begin{abstract}
This study reviews the wireline log responses of some geothermal fields in the Imperial Valley, California. The fields under study include the Heber, the East Mesa, the Brawley, and the Westmoreland. The well logs used in the study did not include all the wireline surveys obtained by the operators. The selected well logs obtained under special arrangements with the operators were chosen to maintain the anonymity of specific well locations but are only representative of each area.

Analysis of the well logs indicates that on an individual field basis, the well logs are excellent for correlation purposes. The presence of extremely saline fluids in some fields precludes the monitoring of $Q_{v}$ (cation exchange capacity per unit volume) profile for detection of hydrothermally altered zones. The producing sections in all the fields are characterized by low porosity and high resistivity.
\end{abstract}

\title{
I. INTRODUCTION
}

In a recently published report, the results of well log interpretation in the Cerro Prieto geothermal field in Mexico were discussed. In brief, the interpretation work on these logs indicated that the monitoring of the hydrothermal alteration effects on low-temperature clays and the detection of zones with altered clays may serve as a usefur exercise in the delineation of target production zones.

This study investigated the application of these findings from cerro Prieto to the well logs in some of the fields in the Imperial valley, California. This study would have been more complete if all the wireline logs of the wells drilled in the Imperial Valley had been examined. Unfortunately, only a few well logs were made available; they are listed in 
Table 1. However, even with the limited amount of wireline logs, some of the findings reported here are significant and warrant further examination by the operators in the area with access to more information.

The well logs included here belong to the Brawley, the Heber, the Westmoreland, and the East Mesa fields. Concurrent with the task of log interpretation, a literature review was conducted to obtain as much information as possible about each field. In the following sections, a brief review of the geological and reservoir data available on individual fields is made, the research steps are outlined, the results of the interpretative work are presented, and finally, these results are compared among the different fields.

II. HYOROTHERMAL GEOTHERMAL FIELDS IN THE IMPERIAL VALLEY

The geothermal fields in the Imperial Valley are part of the Saltion Trough. The trough covers an area of $26000 \mathrm{~km}^{2} .^{2}$ The sedimentary column in the trough consists of interbedded alluvial gravels and sands, eolian silts and sands, and lacustrine silts and clays. ${ }^{3}$

TABLE I

LIST OF WELL LOGS

\begin{tabular}{|c|c|c|c|}
\hline Field & Well & Operator & Well Logs \\
\hline \multirow[t]{2}{*}{ Brawley } & A & Union 0il co. of California & DIL, CNFD \\
\hline & B & Union 0 il Co. of California & DIL, CNFD \\
\hline Mesa & $6-1$ & U.S. Bureau of Reclamation & DIL, CNFD \\
\hline \multirow[t]{3}{*}{ Heber } & A & Chevron Resources & DIL, CNFO \\
\hline & B & Chevron Resources & DIL, CNFD \\
\hline & C & Cherron Resources & DIL, CNFD \\
\hline \multirow[t]{4}{*}{ Westmore land } & 1 & Republic Geothermal & DIL, CNFD \\
\hline & 2 & Republic Geothermal & DIL, CNFD \\
\hline & 3 & Republic Geothermal & DIL, CNFD \\
\hline & 4 & Republic Geothermal & DIL, CNFD \\
\hline
\end{tabular}


The Imperial Valley is wedge shaped with a flat, alluviated floor. Numerous strike-slip faults of the San Andreas-San Jacinto system control the structure of the valley. ${ }^{4}$

According to a publication by the U.S. Geological Survey, ${ }^{5}$ the total thermal energy in the Salton Trough has been estimated at $240 \times 10^{8} \mathrm{~J}$ with an undiscovered potential of another $480 \times 10^{8} \mathrm{~J}$.

The significant energy potential of these hydrothermal geothermal fields in the Imperial valley has been the impetus for the extensive expioration and development during the last two decades. Several major fields have been discovered. Figure 1 shows the location of some of the geothermal fields in the Imperial Valley. The depth to the producing zones ranges from $1000 \mathrm{~m}$ (Salton Sea) to $5000 \mathrm{~m}$ (South Brawley). Power plants currently on line include Magma's binary cycle at East Mesa, Edison's power plant at Brawley, and the ones at Salton Sea and Niland. Based on detailed studies of the cores and drill cuttings, indications are that the sediments are at various stages of diagenesis and alteration. ${ }^{6,7}$ The rocks cover the

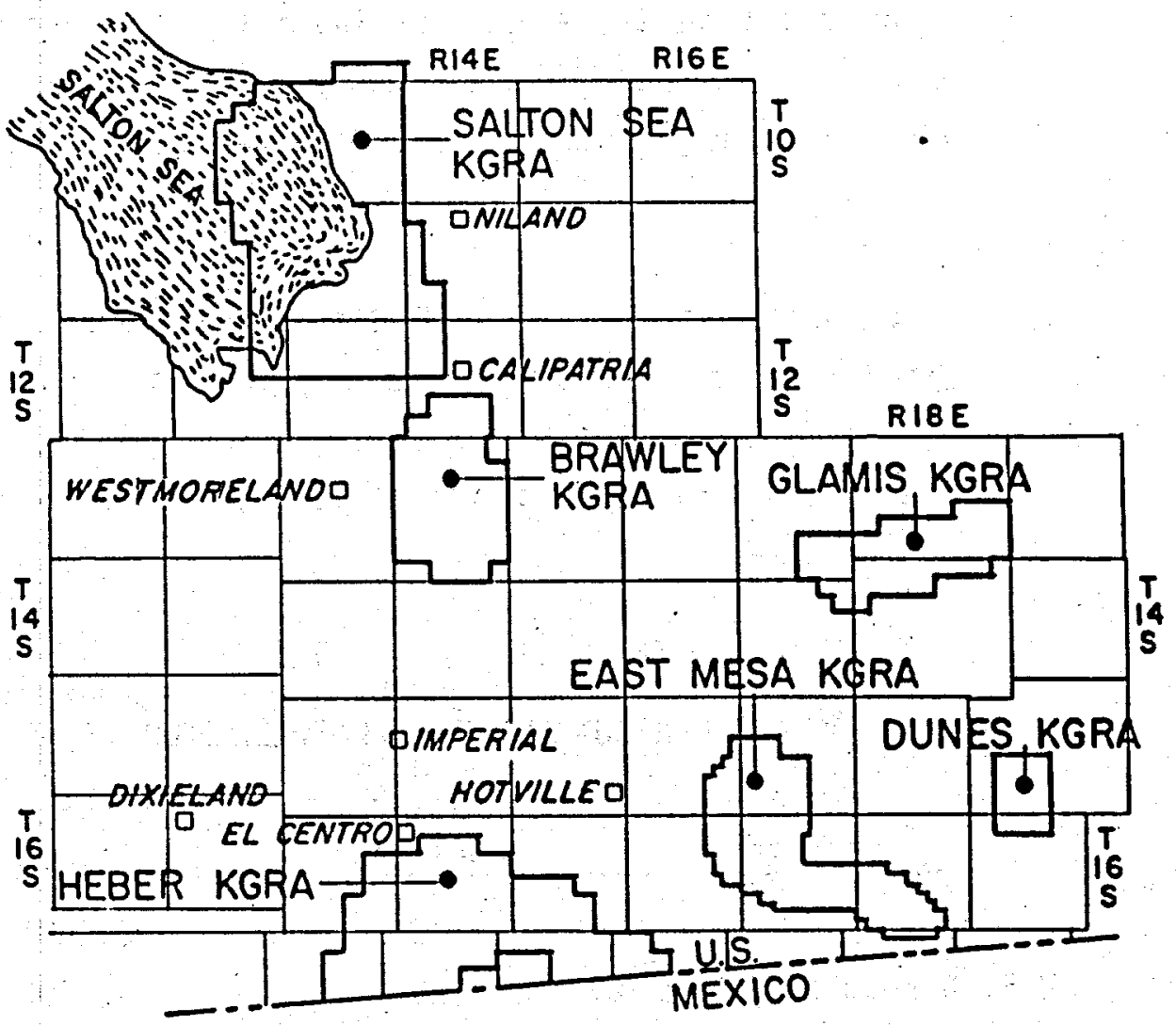

Fig. 1.

Location of some geothermal fields in the Imperial Valley. 
spectrum from unaltered, unconsolidated sands, clays, and silts to highly. indurated and altered sandstones, siltstones, and shales.

Various fields discovered in the Imperial Valley show large differences in formation-brine salinity, temperature, porosity, and permeability. ${ }^{8}$ The two key factors in the commercialization of the fields are the salinity and temperature. Salinities in the area range from less than $2000 \mathrm{ppm}$ at East Mesa to more than $300000 \mathrm{ppm}$ in the Salton Sea field. The temperature ranges from 160 to $320^{\circ} \mathrm{C}$.

Extensive field and research reports have appeared in the literature on certain areas such as the East Mesa. ${ }^{6-8}$ Information published about others such as the Brawley field is very limited.

Table II is a summary, comparing the characteristics of the different fields.

Studies of subsurface structure of sedimentary geothermal systems require mud log data, wireline logs, and core data. Generally the use of wireline logs to study the geothermal fields has been downplayed because of temperature limitation of existing tools or the inability to interpret the results. The limitation on interpolation is because of lack of adequate calibration data. Calibration facilities have recently become available. ${ }^{9}$

\section{PURPOSE OF THE STUDY}

This study was conducted to examine if the conventional well logs routinely run in geothermal wells can demonstrate any property indicative of the potential production zones. Furthermore, a comparison of the well log responses among various fields throughout the Imperial Valley was deemed desirable.

TABLE II

GENERAL INFORMATION ABOUT THE FIELDS UNDER STUDY

\begin{tabular}{|c|c|c|c|c|}
\hline Field & Operator & $\begin{array}{l}\text { No. of } \\
\text { Weils }\end{array}$ & $\begin{array}{c}\text { Salinity } \\
\text { (ppm) }\end{array}$ & $\begin{array}{l}\mathrm{BHT} \\
\left({ }^{\circ} \mathrm{C}\right) \\
\end{array}$ \\
\hline Brawley & Union 0 il & 10 & 200,000 & 260 \\
\hline East Mesa & U.S. Bureau of Reclamation & 20 & 2,500 & 204 \\
\hline Heber & Chevron Resources & 17 & 14,000 & 190 \\
\hline Westmoreland & Republic Geothermal, Inc. & 6 & $\begin{array}{l}20,000- \\
70,000\end{array}$ & 260 \\
\hline
\end{tabular}


Three major operators in the Imperial Valley agreed to furnish us with some limited amount of well logs. To protect the operators against the misuse of the data, the well logs were provided on the condition that we refrain from identifying the exact surface location and certain depth aspects of the wells.

It would have been highly desirable if the authors had had access to the complete suite of logs for all wells plus other available information such as drilling records, mud logs, and any core analyses. But in the absence of such complete data, it is believed that the limited information used here is still a significant step in developing an overall picture of the similarities and differences among the fields in the area.

It was fortuitous that all the logs received and used in this study were recorded by the same service company. Variations in the log data because of externally controlled parameters such as the properties of the drilling fluids, were normalized to compare the log-derived parameters.

IV. METHOD OF STUDY

The well logs were manually digitized for various computational purposes. For each well under study, a number of permeable beds throughout the entire depth column were selected for detailed studies and comparative evaluation.

The variation of certain log-derived values such as spontaneous potential (SP), gamma ray (GR), neutron porosity $\left(\phi_{N}\right)$, resistivities of the deep induction $\log \left(R_{I L D}\right)$ and Laterolog $8\left(R_{L L 8}\right)$ were statistically analyzed, and the mean values were plotted on spiderweb diagrams. The diagrams were arranged according to the depth of the permeable sections.

Several cross plots were prepared to study certain characteristics of the permeable sections from two independently measured parameters. These cross plots included the cross plots of both $R_{I L D}$ and $R_{L L 8} v s \phi_{D}$ and $\phi_{D}$ vs $\phi_{N}$

The procedure of computing $\left(Q_{v}\right)$ sand was applied to the digitized parameters, and attempts were made to determine the depth profile of the cation exchange capacity per unit volume of the permeable zones.

Finally, the well logs were scrutinized for detection of unusual effects on various recorded parameters. Included in this aspect of study were the reversal of position of $R_{\text {ILD }}$ with respect to $R_{L L 8}$, excessive or 
negative correction on the density logs, and borehole problems as evident from the caliper log.

\section{REVIEW OF LOG-DERIVED PARAMETERS}

Before the well logs were digitized for computational aspects of the study, a quality check was made as to the acceptability of the furnished information. Using various overlays, repeat sections, and the calibration check, the well logs were found to be generally of good quality with some exceptions where tool problems prevented the recording of some curves beyond a certain depth. Oftentimes, the temperature-related problems prevented the continuous recording of resistivity or other curves.

VI. ANALYSIS OF WELL LOG DATA

As indicated before, the purposes of this study were first to see the similarities among the well logs from various fields of the Imperial valley and second to establish the features on the logs that infer the presence of hydrothermal zones.

In terms of correlation across the Valley, the spiderweb diagrams were used to observe general trends of various parameters with depth. These trends for different fields are summarized in Table III.

In general, the features common among various fields include the following:

- increase of the $R_{L L 8}$ with depth,

- increase of the RILD with depth, and

- decrease of $\phi_{N}$ and $\phi_{D}$ with depth.

TABLE III

SUMMARY OF WELL LOG RESPONSES AS OEPTH INCREASES

\begin{tabular}{|c|c|c|c|c|c|c|c|}
\hline Well & $R_{L L 8}$ & ${ }^{\mathrm{R}}$ ILO & $R_{\text {sand }} / R_{\text {shale }}$ & ${ }^{\circ}$ sand $/ \rho_{\text {shale }}$ & $\phi_{N}$ & $\Phi_{0}$ & $\begin{array}{c}R_{w} \text { from } \\
\text { Cross P Plot }\end{array}$ \\
\hline Mesa 6-1 & increase & increase & $\leq 1$ & $<1$ & decrease & decrease & decrease \\
\hline Brawley $A$ & increase & increase & $\geq 1$ & $<1$ & decrease & decrease & increase \\
\hline Brawley: B & increase & increase & $>1$ & $<1$ & decrease & constant & increase \\
\hline Heber A & increase & increase & $>1$ & $<1$ & decrease & decrease & constant \\
\hline Heber $\mathrm{C}$ & increase $^{a}$ & increase $^{a}$ & $>1$ & $\leq 1$ & decrease $^{a}$ & decrease & decrease \\
\hline Wes tmorel and 2 & increase & increase & $>1$ & $<1$ & decrease $^{a}$ & decrease $^{\mathrm{d}}$ & increase \\
\hline Westmore 1 and 3 & increase & increase & $<1$ & $<1$ & decrease & decrease & decrease \\
\hline
\end{tabular}

Change in direction is noted. 
Figures 2-5 show these typical trends for well Heber $A$. The depth trend of other log-derived values such as SP and GR have shown inconsistencies among the different fields.

The next phase of this study focuses on the explanation of these trends. The loss of electrical conductivity with depth may be caused by one or the combination of the following:

- a drop in the formation-brine salinity,

- a drop in formation porosity, and

- a drop in surface conductivity of clays.

The possibility of a drop in formation-brine salinity with depth can be ruled out on some wells when checked against the field evidence of high-salinity fluids from these fields. These can also be verified by studying the resistivity-porosity cross plots for various wells. Wells Mesa 6-1, Heber C, and Westmoreland 3 indicate lower $R_{W}$ 's for deeper sands. Other wells such as Brawley A, Brawley B, and Westmoreland 2 show evidence of an increasing trend in $R_{w}$ with depth. Heber $A$ shows relatively constant $R_{w}$ depth profile. Figures 6-8 show some typical resistivity-porosity cross plots.

While the change in $R_{W}$ may be responsible for the resistivity increase on some logs, its contribution to the overall change lessens when one considers the behavior of the $R_{L L 8^{\circ}}$ For example, as shown in Fig. 9, Mesa 6-i from a cross plot of $R_{L L 8}$ vs $\phi_{D}$ shows uniform $R_{m f}$ with depth, while both $R_{L L 8}$ and $R_{I L D}$ increase with depth. Since for this well $R_{W}$ decreases with depth, the cause of formation-resistivity increase must be the other two factors, namely, a decrease in porosity or a decrease in the surface conductivity of formation. Similar observations can be made with respect to Heber $C$ and Westmoreland 3. Some exceptions ae Brawley A, B, and Heber $A$. But the same process affecting Mesa 6-1, Heber $C$, and Westmoreland 3 may have affected the others.

To examine the changes in porosities with depth, depth plots of $\phi_{D}$ and $\phi_{N}$ were made for individual wells. All wells indicate a definite drop in porosity as recorded from both the density $\log$ and the neutron $10 \mathrm{~g}$. Figures 10-11 show such typical trends for well Brawley $A$. The indicated drop of porosity alone can account for the increase in $R_{L L 8}$ and $R_{\text {ILD }}$ with depth regardless of changes in $R_{w}$. We must examine the cause and the nature of the porosity reduction with depth as this results in some clues for subsurface exploration of hydrothermal zones. 


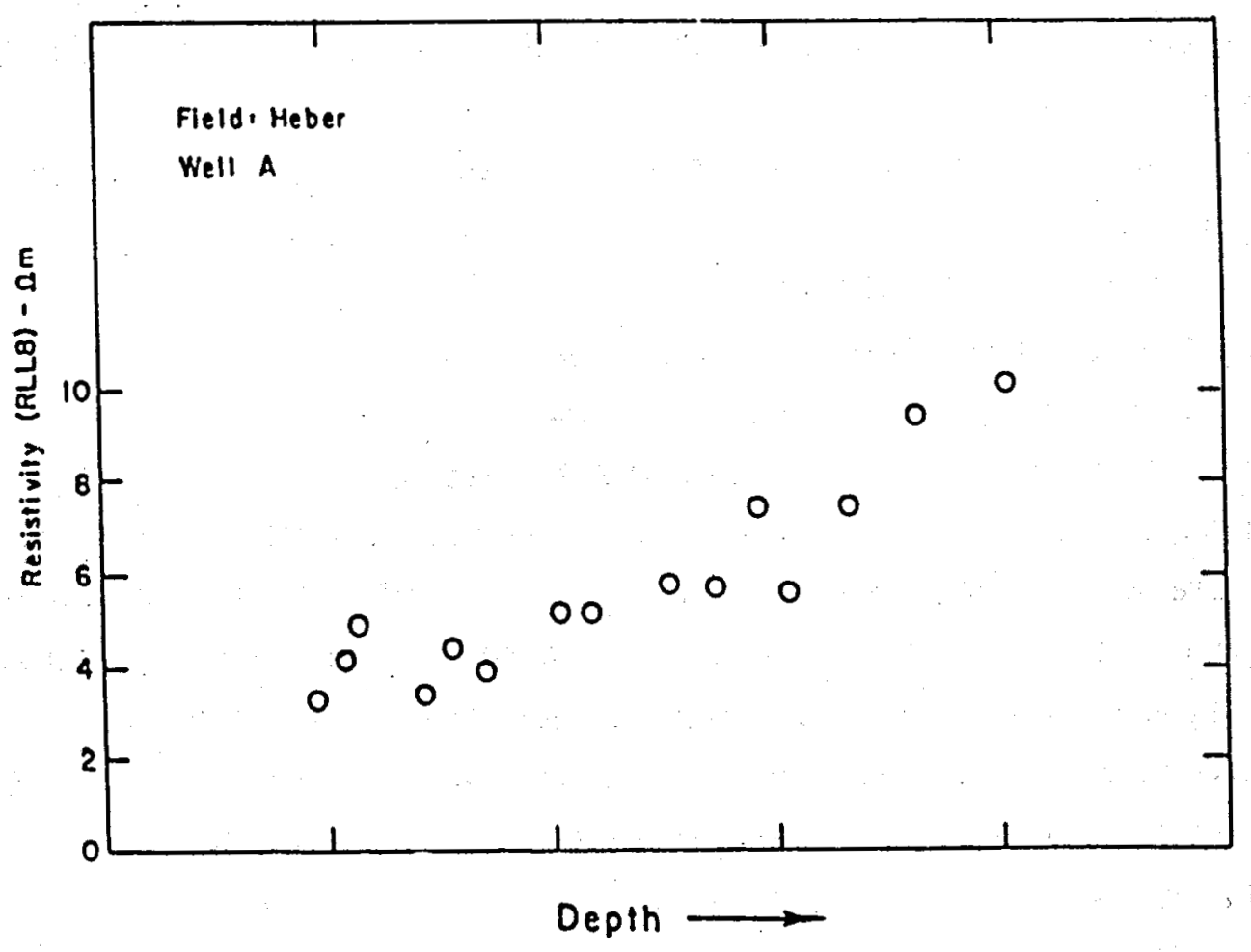

Fig. 2.

Heber A - RLL8 vs depth.

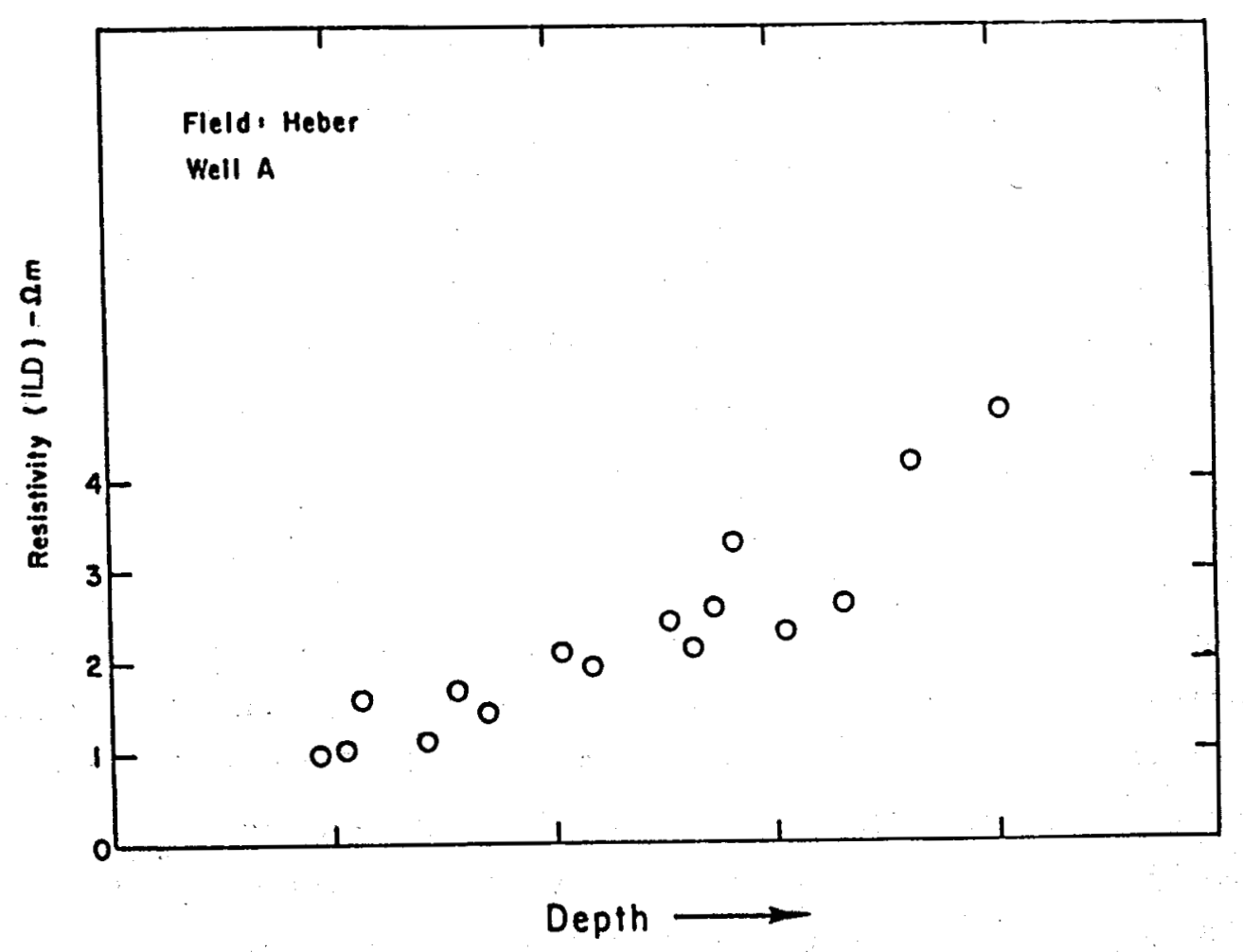

Fig. 3.

Heber A - RILD vs depth. 


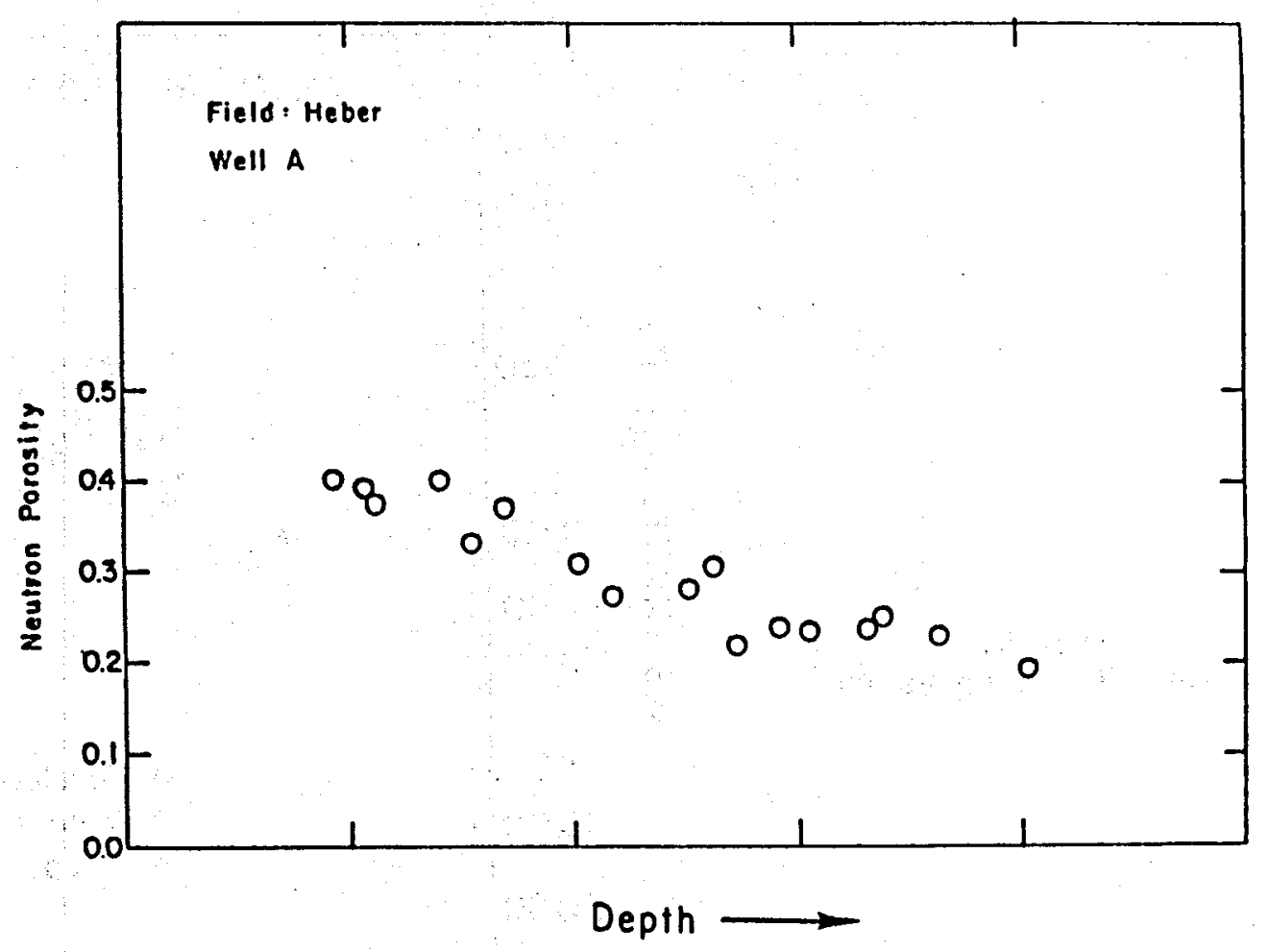

Fig. 4.

Weber $A-\phi_{N}$ vs depth.

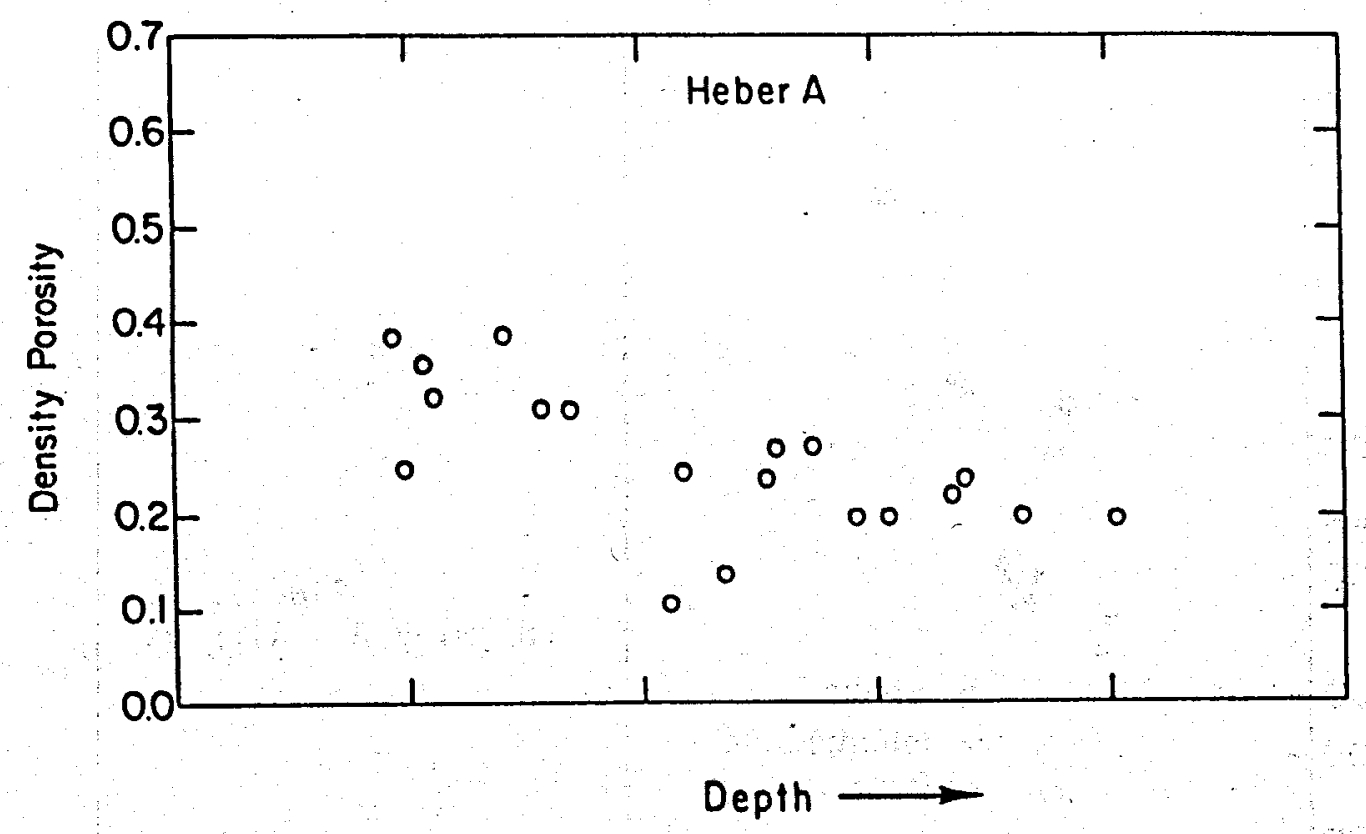

Fig. 5.

Weber $A-\phi_{D}$ vs depth.

9 
Fig. 6 .

Westmoreland $3-R_{I L D}$ vs $\phi_{D}$.
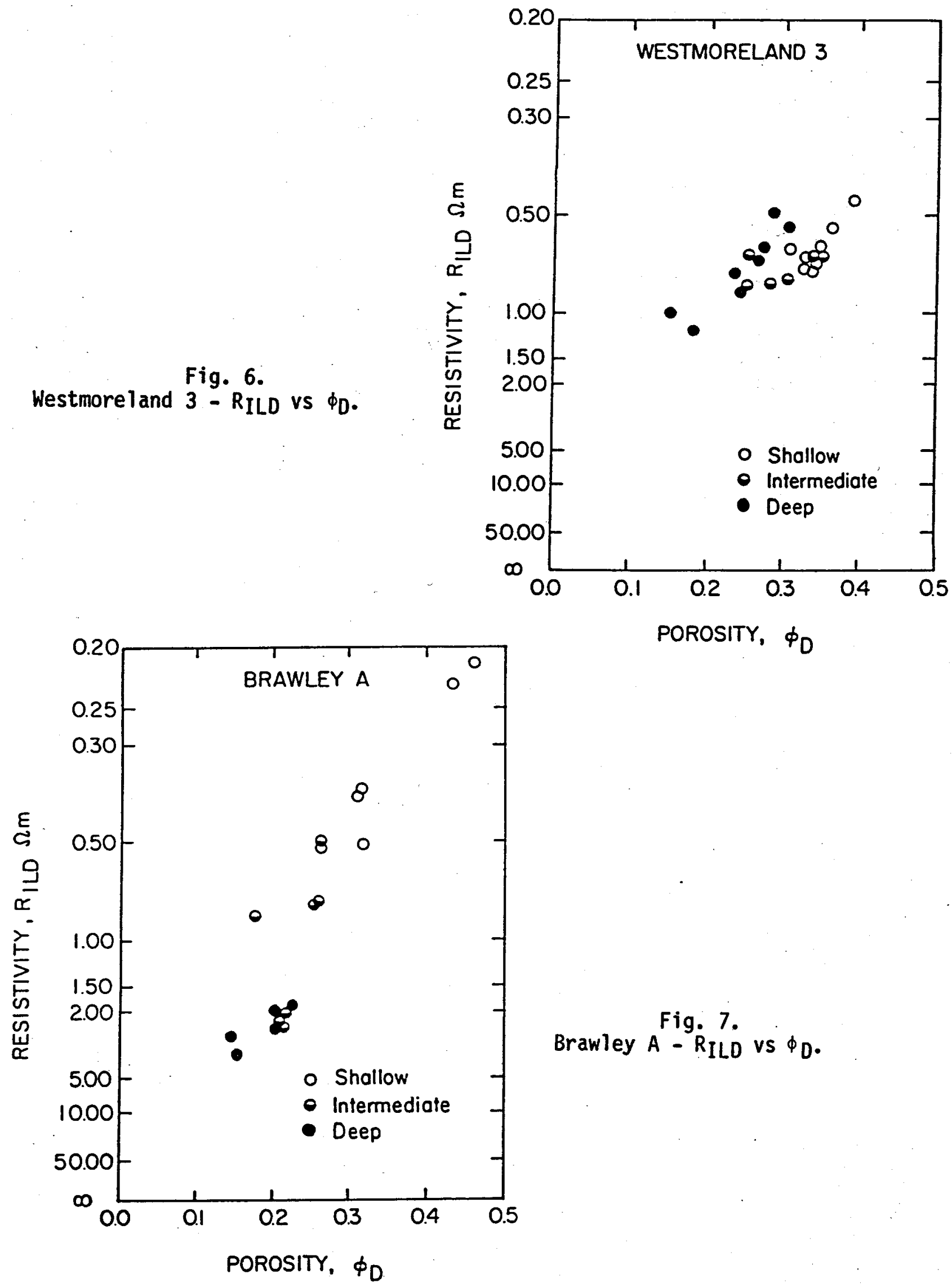

Fig. 7.

Brawley $A-R_{I L D}$ vs $\phi_{D}$. 
Fig. 8.

Heber A - RILD VS $\phi_{D}$.
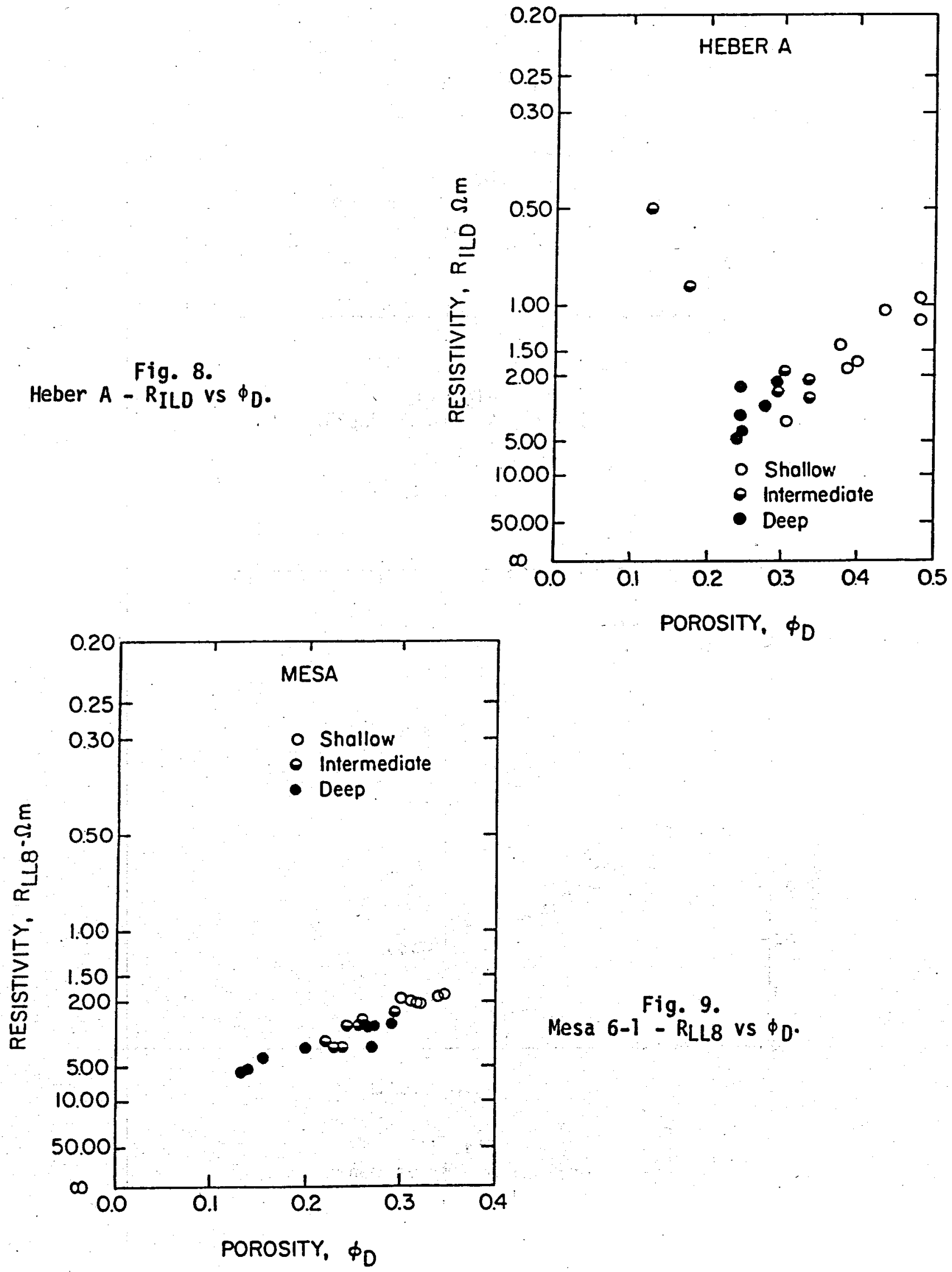

Fig. 9.

Mesa $6-1-R_{L L 8}$ vs $\phi_{D}$. 


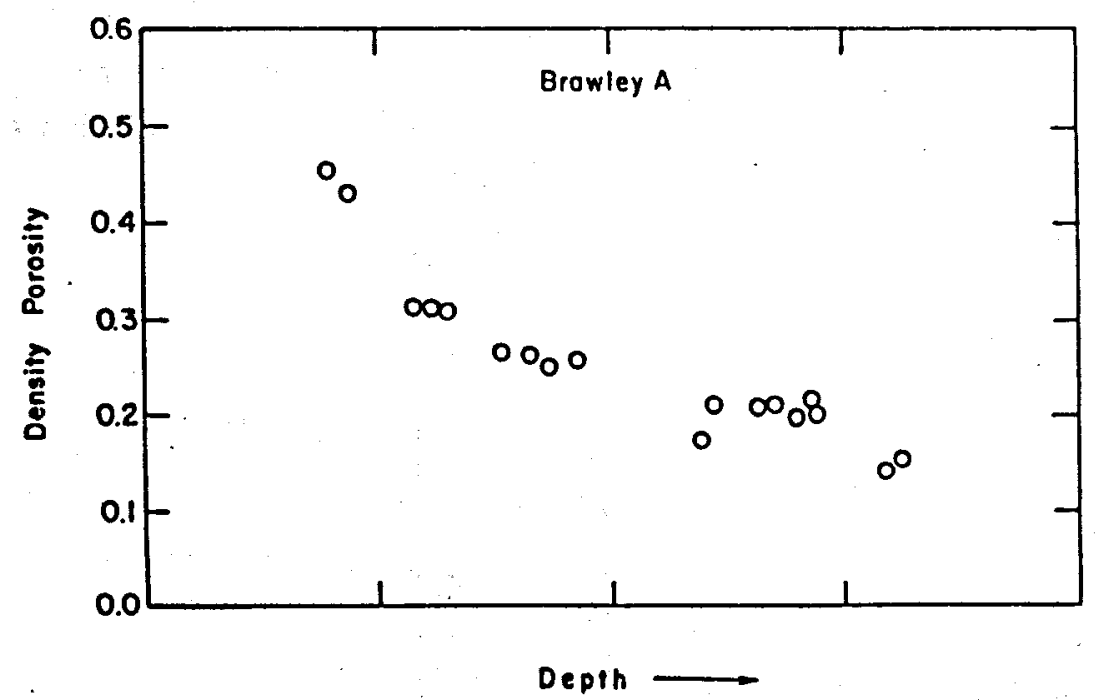

Fig. 10.

Brawley $A-\phi_{D}$ vs depth.

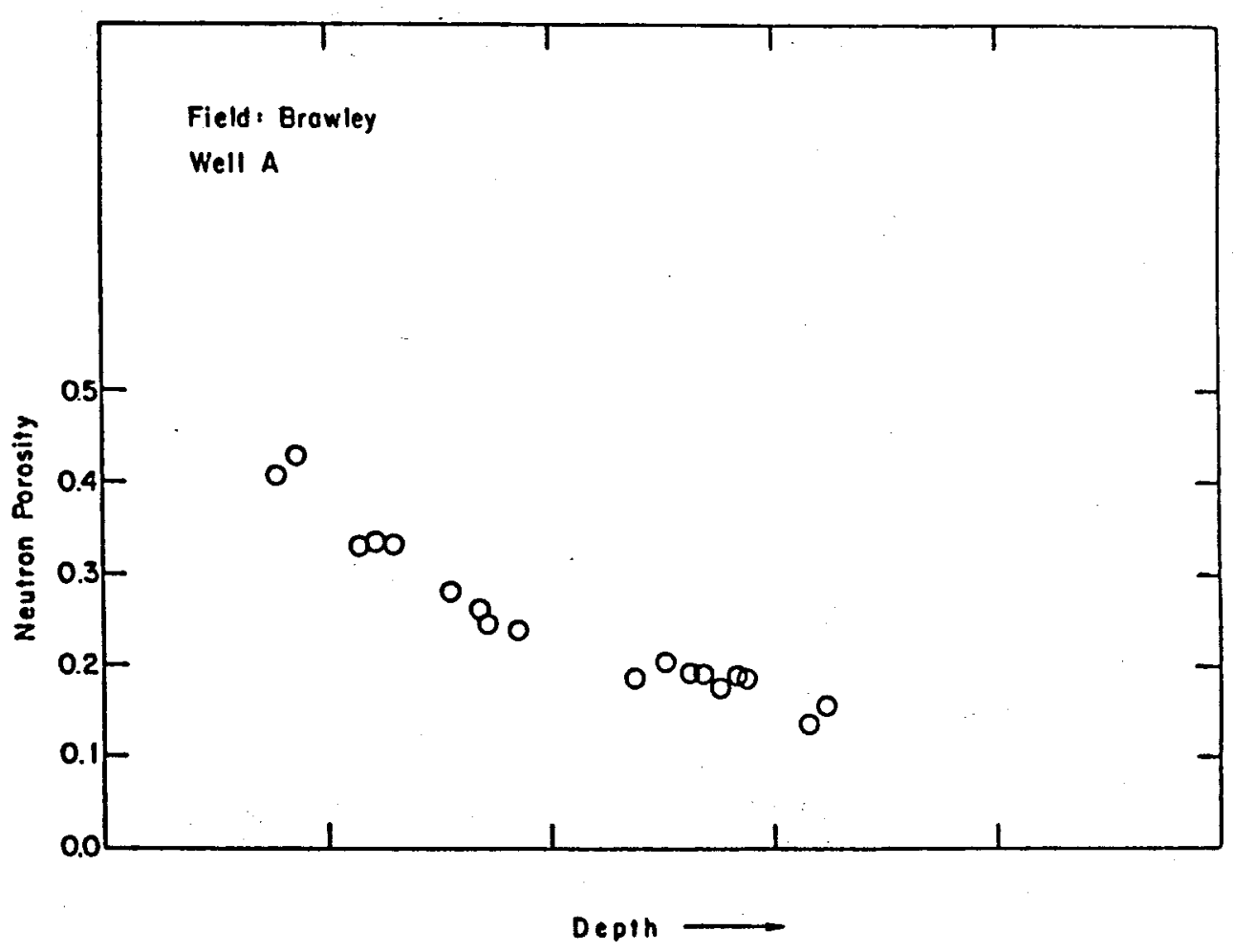

Fig. 11.

Brawley $A-\phi_{N}$ vs depth. 
If the drop is merely a reflection of sediment compaction with depth, both the $\phi_{D}$ and $\phi_{N}$ must show porosity reduction while the $\phi_{N}>\phi_{D}$ relationship is maintained because of the shaly nature of the original sediments. But as shown in Figs. 12 and 13 for wells Brawley $A$ and Heber $C$, the cross plots of $\phi_{D}$ vs $\phi_{N}$ indicate that a line with a unit slope can represent the data points for the deep formations. This means the loss of bound water for the formation. The loss of bound water can be attributed to thermal alteration of clays. These alterations happen if hydrothermal fluids have found their way through the permeable beds to affect the various constituents of the rock.

The loss of bound water and the apparent absence of active clays can also account for the loss of surface conductivity and thus an increase in formation resistivity.

It is interesting to note that the plots of $R_{\text {sand }} / R_{\text {shale }}$ correlate very well with the observation made earlier with respect to the changes of $R_{W}$ with depth. For all cases where the cross plots indicate an increase of $R_{w}$ with depth, $R_{\text {sand }} / R_{\text {shale }}$ ratios also increase with depth. Figure 14 is an example for Brawley $B$. For wells such as Mesa $6-1$ and Westmoreland 3 when a decrease of $R_{w}$ with depth was evident from the cross plot,

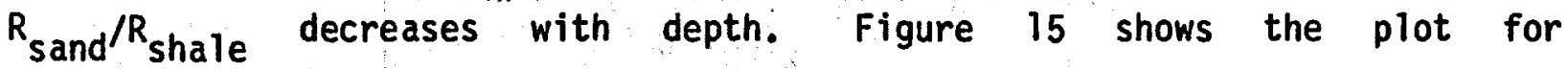
Westmoreland 3. This observation points out the nature of the invading brines in the permeable sections and provides a comparison with the original brine of the sedimentary column trapped in the shales. This ratio change, because of salinity variation, is further confirmed when the relationship of $\left(\rho_{b}\right)_{\text {sand }}$ and $\left(\rho_{b}\right)_{\text {shale }}$ is examined on various logs. As shown in Figs. 16-17, this bulk-density ratio is less than unity indicating the salinity change above is the cause of increasing or decreasing the trend in $R_{\text {sand }} / R_{\text {shale }}$

As a further check, the procedure for estimating $Q_{v}$ profile ${ }^{10}$ with depth was employed here, and the results for Brawley $B$ and Westmoreland 2 are shown in Figs. 18-19. In general, the patterns observed in the case of Cerro Prieto wells are not consistently seen here. This can be explained because either mineralogical differences exist between the formations studied here and Cerro Prieto or the inconsistencies observed on the SP $\log$ affect the computations. 


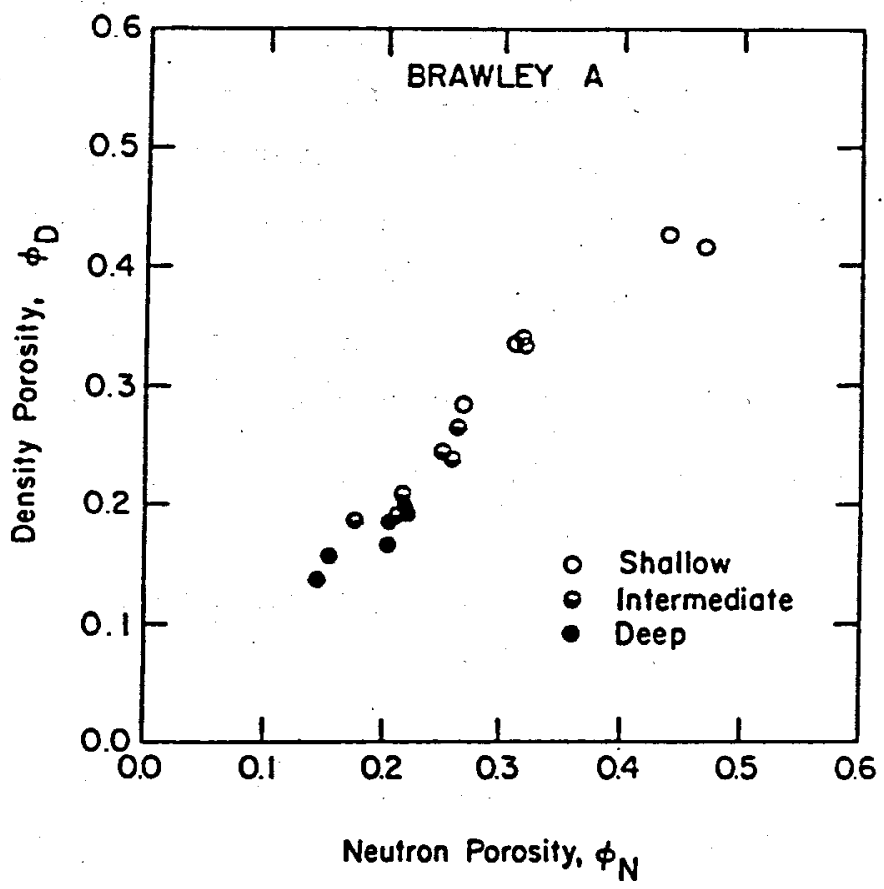

Fig. 12.

Brawley $A-\phi_{D}$ vs $\phi_{N}$.

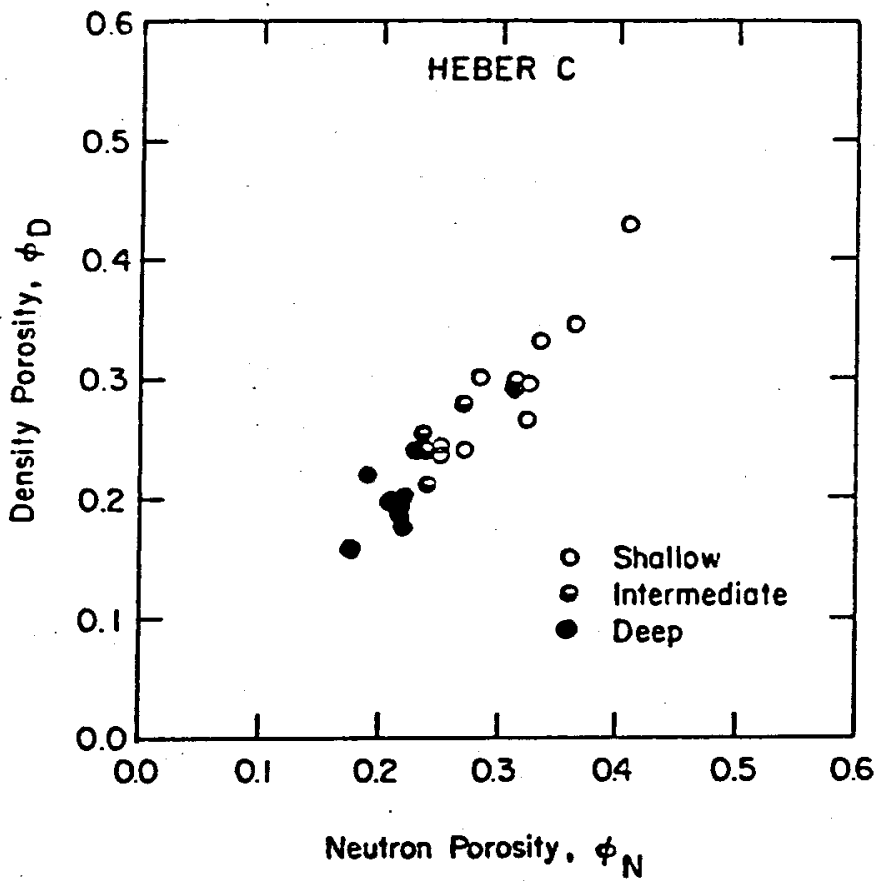

Fig. 13.

Heber $C-\phi_{D}$ vs $\phi_{N}$. 

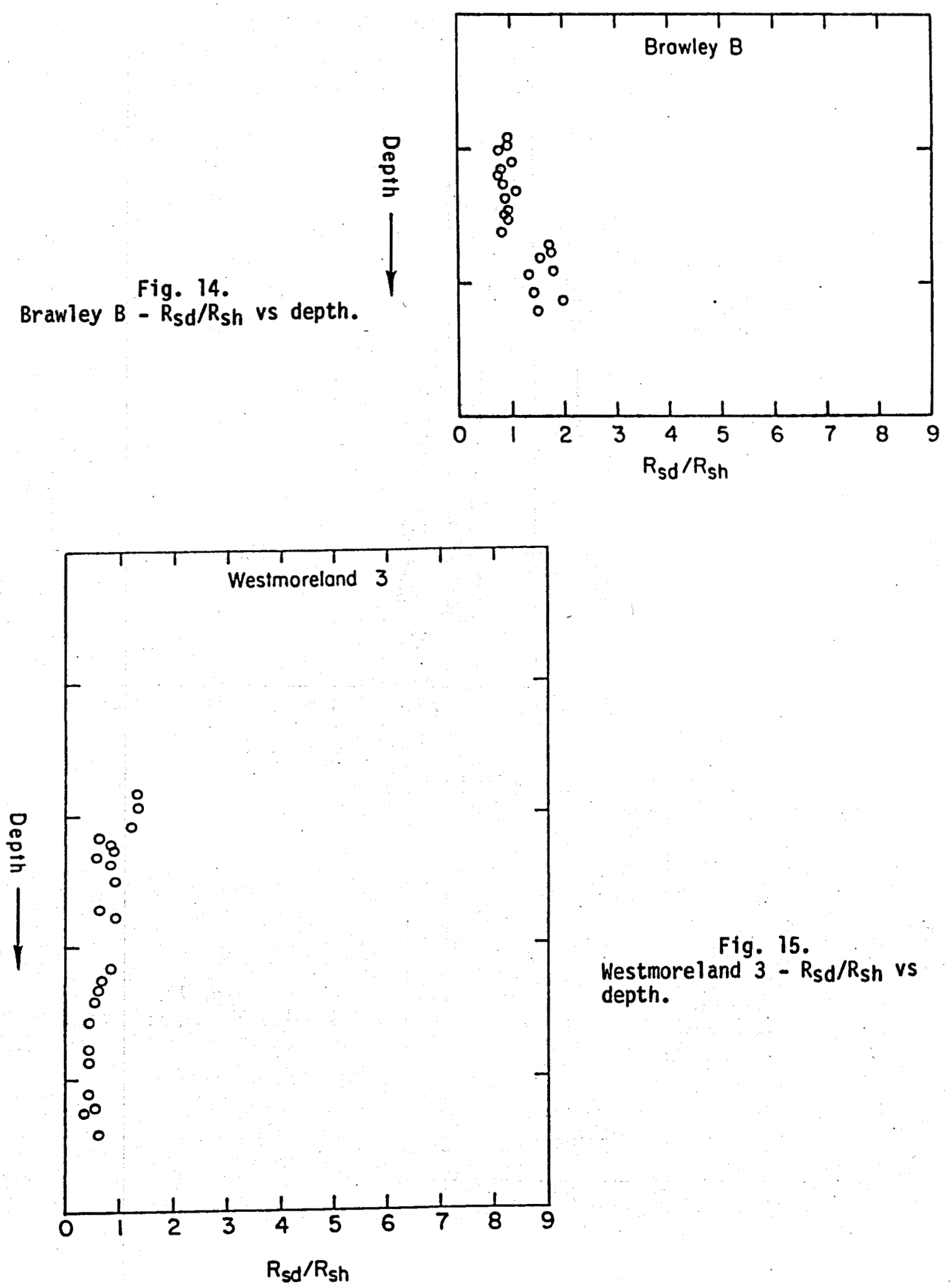
Fig. 16.
Mesa $6-1-\rho_{b}$ vs depth.
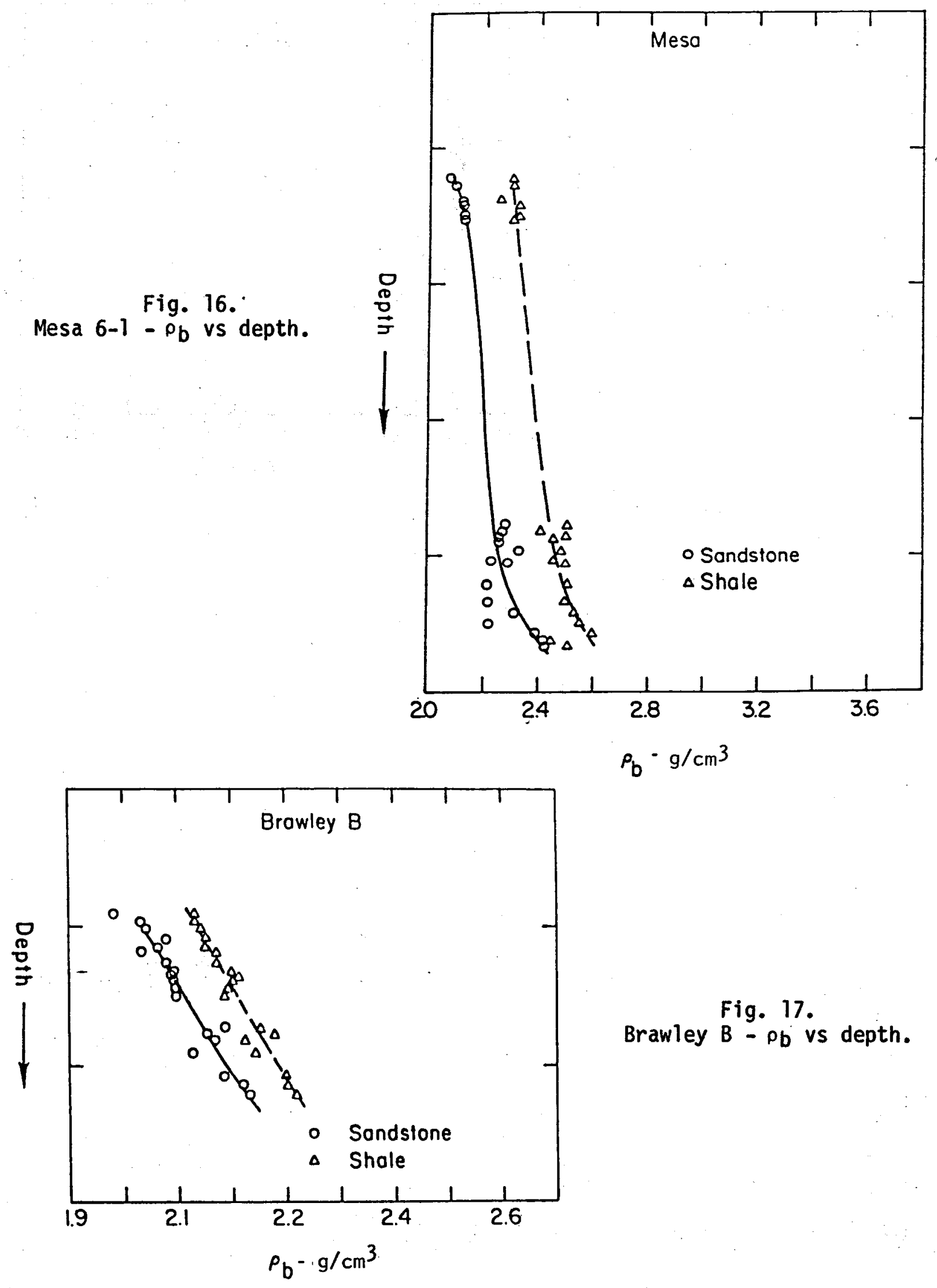


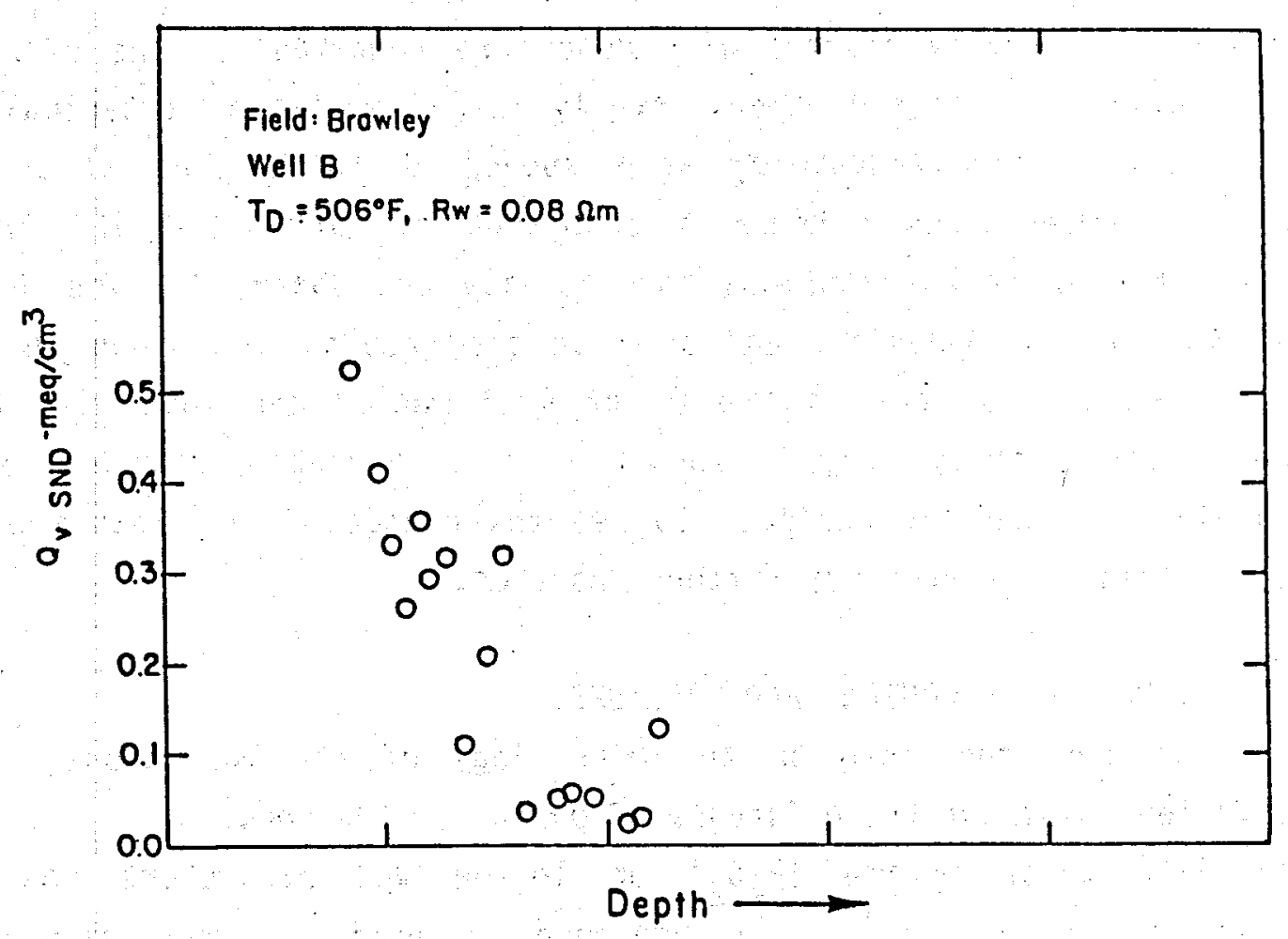

Fig. 18.

Brawley B - Qv vs depth.

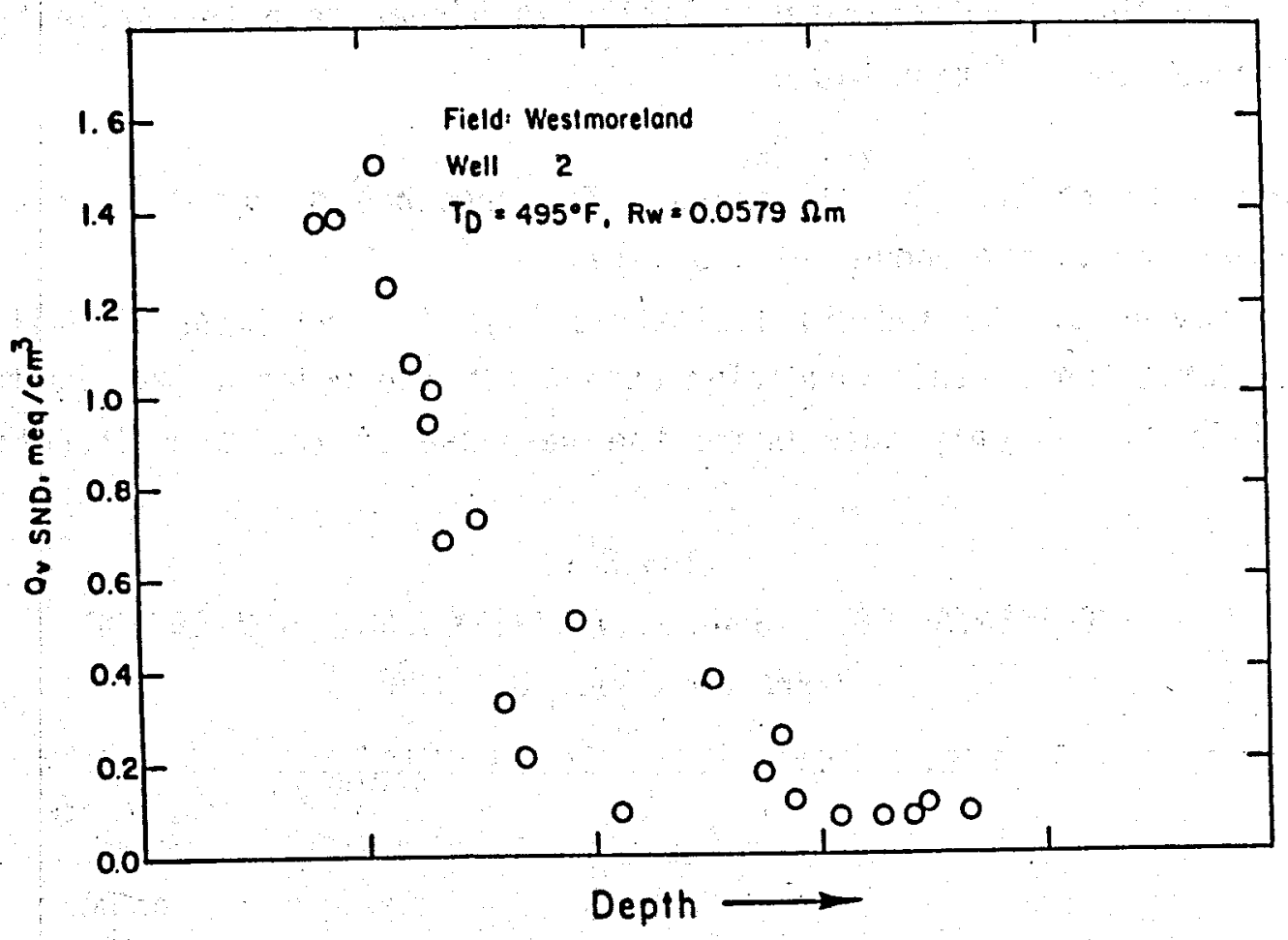

Fig. 19.

Westmoreland $2-Q_{v}$ vs depth. 
The effect of hydrothermal alteration on both the $\phi_{N}-\phi_{D}$ cross plots and the resistivity changes with depth are remarkable. The effect on resistivity alone was checked experimentally where samples of a typical clay containing rock (Berea sandstone) were subjected to boiling under high pressure and temperatures. Under a condition of $300^{\circ} \mathrm{C}$ and $183 \mathrm{kPa}, \mathrm{a}$ significant drop in rock electrical conductivity was observed. The details are discussed in the Appendix, and some of the results are shown in Table IV. A brine-saturated rock with a $Q_{v}$ of $0.21 \mathrm{meq} / \mathrm{m} \ell$ can lose $21 \%$ of its electrical conductivity by exposure to high-temperature brine. Unfortunately, we were not equipped to see the changes in $\phi_{N}$ losses due to boiling, but this is an area for further research.

\section{EFFECT OF PYRITE CONTENT AND FRACTURES}

Some studies published on the mineralogy of the formations in the Imperial Valley point out the existence of pyrite in the rocks.

The effect of pyrite $\left(\mathrm{F}_{e} \mathrm{~S}_{2}\right)$ on log-derived parameters has been studied by $\mathrm{Clavier}$ et al. ${ }^{11}$ The presence of pyrite causes significant changes in the measured bulk density and the resistivity from the induction log.

Since the formation-water salinity is higher than the salinity of the mud filtrate, the relationship of

$$
c_{w}>C_{x 0}
$$

is expected to be true at all times. The presence of pyrite, if any, will tend to exacerbate the above relationship.

A review of the induction electric logs for the Imperial Valley wells shows no deviation to this condition except for two wells in the Westmoreland area. This is the only case where the response of the deep induction logs

\section{TABLE IV}

EXPERIMENTAL RESULTS ON RESISTIVITY AND $Q_{v}$ CHANGES OF BEREA ROCK WITH BOILING

\begin{tabular}{|c|c|c|c|c|c|}
\hline \multirow[b]{2}{*}{ Core } & \multirow[t]{2}{*}{ Resistivity, $\Omega \mathrm{m}$, before boiling } & \multirow{2}{*}{$\begin{array}{l}\text { Resistivity, } \\
\text { Measured }\end{array}$} & \multirow{2}{*}{$\begin{array}{l}\text { om; after boiling } \\
\text { Calculated by } \\
\text { Eq. (A-1) } \\
\text { (without } B Q v \text { ) }\end{array}$} & \multicolumn{2}{|c|}{$0_{y}$ meq/m $\ell$ of PV } \\
\hline & & & & $\begin{array}{l}\text { Resistivity } \\
\text { Method }\end{array}$ & $\begin{array}{l}\text { Chemical } \\
\text { Method }\end{array}$ \\
\hline$\#$ & 2.506 & 3.200 & 2.8300 & 0.21353 & 0.20763 \\
\hline$\# 2$ & 2.7140 & 3.667 & 3.1332 & 0.1462 & 0.1223 \\
\hline$\# 3$ & 1.5630 & 1.8755 & 1.8013 & 0.05744 & 0.1056 \\
\hline
\end{tabular}


WESTMORELAND I

Fig. 20.

Resistivity reversal in Westmoreland 1.
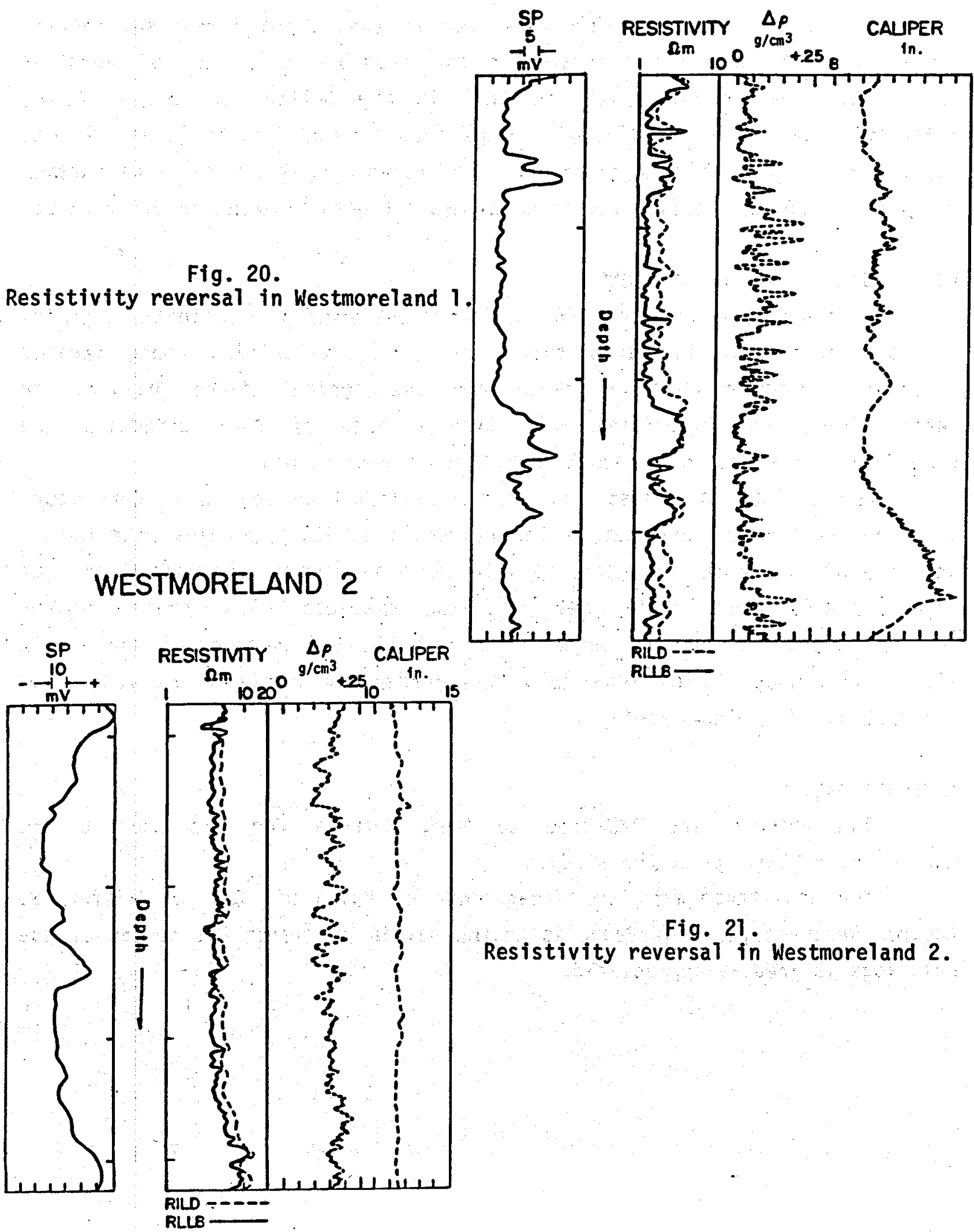

Fig. 21 .

Resistivity reversal in Westmoreland 2 . 
indicates lower conductivities than those obtained from Laterolog 8 , Figs. 20 and 21.

The major causes of this reversal are the salinity reversal between formation fluid and mud filtrate or the possible existence of vertical fractures. The proximity of the well to the Salton Sea area and the information on the log heading with respect to the mud resistivities preclude the assumption of salinity reversal. The presence of fracture needs further analyses, since the resistivity reversal has not been observed in other wells.

\section{SUMMARY AND CONCLUSIONS}

Review of the well logs from certain geothermal fields in the Imperial Valley, California, indicates that there are similarities among various recorded parameters. Among these are the typical depth profiles of resistivities and porosities, indicating a loss of both effective and noneffective porosities caused by hydrothermal alterations.

cross plots of resistivity from deep induction $\log v s \phi_{D}$ were found to serve as a convenient method for detecting salinity changes with depth. The loss of electrical conductivity with depth is also a clue when the target zones are approached. Such zones are further characterized by cross plots of $\phi_{N}-\phi_{D}$ where the loss of bound water results in clustering of the points along a unit slope line. Problems with recorded SPs precluded the widespread application of $Q_{v}$ depth profile.

\section{ACKNOWLEDGMENTS}

The authors are indebted to Mark Mathews for his support and encouragement throughout the study.

The assistance from the managements of Union 0il Co. of California, Chevron Resources, and of Republic Geothermal in providing the copies of the well logs is greatly appreciated. 


\section{REFERENCES}

1. Ershaghi, I., Ghaemian, S., and Abdassah, D., "Lithology and Hydrothermal Alteration Determination from Well, Logs for the Cerro Prieto Wells, Mexico," Los Alamos National Laboratory report LA-9075-MS (October 1981).

2. Elders, S. A., Rex, R. W., Meidav, T., Robinson, P. T., and Biehler, S., "Crustal Spreading in Southern California," Science 178, 15-241 (1972).

3. Hoagland, J. R., "Petrology and Geochemistry of Hydrothermal Alteration in Borehole Mesa 6-2; East Mesa Geothermal Area, Imperial Valley, California," M.S. thesis, University of California Riverside (1976).

4. Biehler, S., Kovach, R. L., and Allen, C. R., "Geophysical Framework of the Northern End of the Gulf of California Structural Province," in Marine Geology of the Gulf of California: American Association of Petroleum Geologists, Memoir 3, 126-143 (1964).

5. Brook, C. A., Mariner, R. H., Mabey, D. R., Swanson, J. R., Guffanti, M., and Muffler, L. J. P., "Hydrothermal Systems with Reservoir Temperatures $<90^{\circ} \mathrm{C}$," in Assessment of Geothermal Resources of the United States 1978, U.S. Geological Survey Circular 790, 48 (1979).

6. Miller, K. R. and Elders, W. A., "Geology, Hydrothermal Petrology, Stable Isotope Geochemistry, and Fluid Inclusion Geothermometry of LASL Geothermal Test Well C/T-1 (Mesa 31-1), East Mesa, Imperial Valley, California, U.S.A.," LOS Alamos Scientific Laboratory report LA-8515-MS (September 1980).

7. White, D. E. and Muffler, L. J. P., "Metamorphism of Upper Cenozoic Sediments to Greenschist Mineral Assemblages; Salton Sea Geothermal Area, California," Geological Society of America, Special Paper 82 (1964).

8. Anderson, D. N., "The Most Promising Geothermal Fields in the Western United States," presented at the Geothermal Resources Council, Short Course No. 10, Anaheim, California (March 25-26, 1981).

9. Mathews, Mark, "Calibration Models for Fractured Igneous Rock Environments," paper L, SPWLA Transactions (1980).

10. Ershaghi, I. and Ghaemian, S., "Estimation of $Q_{v}$ Profile in a Sedimentary Type Geothermal Reservoir," SPE 9927, presented at the 1981 California Regional Meeting of SPE, Bakersfield, California (March 25-26, 1981).

11. Clavier, C., Heim, A., and Seala, C., "Effect of Pyrite on Resistivity and Other Logging Measurements," paper HA, SPWLA Seventeenth Annual Logging Symposium Transactions (June 9-12, 1976). 


\section{APPENDIX}

EXPERIMENTAL STUDIES OF Q $\mathrm{V}$ MEASUREMENT

In an effort to study the changes in the $Q_{v}$ properties of clay containing rocks when subjected to high-temperature conditions, a series of experiments were conducted. These experiments consisted of measurement of $Q_{v}$ before and after hydrothermal alteration by both the titration method and resistivity measurements.

Core materials used were of the Berea sandstone type selected for this study because of their homogeneous characteristics. The samples used had porosities ranging from 19 to $26 \%$ and permeabilities of 60 to $500 \mathrm{md}$.

The hydrothermal alteration was imposed on the cores by boiling them in a pressurized vessel up to a temperature of $300^{\circ} \mathrm{C}$ for 24 hours. The brine used was $5 \% \mathrm{NaCl}$.

To measure the $Q_{v}$ of the samples before the hydrothermal effects, the resistivities of the saturated cores were measured and compared to the computed resistivities assuming no clay content $\left(c_{0}=c_{w} / F\right)$. From the difference between the two measurements, a value for $Q_{v}$ was obtained from the Waxman-Smits equation

$$
c_{0}=\frac{1}{F}\left(B Q_{v}+c_{w}\right)
$$

where

$$
\begin{aligned}
F & =\frac{0.625}{\phi^{2.15},} \\
B & =\left[1-0.86 \exp \left(-C_{W} / 0.02\right)\right] 0.001 \lambda_{\mathrm{Na}}^{e}, \\
\lambda_{\mathrm{Na}}^{e} & =38.3 \mathrm{~cm}^{2} \text { equiv }^{-1} \mathrm{ohm}^{-1}, \\
Q_{V} & =\text { meq/m } / \mathrm{m} \text { of PV, and } \\
C_{0}, C_{W} & =\text { mho cm }
\end{aligned}
$$


The $Q_{v}$ 's were also measured from the titration method where the core samples were flooded by $0.1 \mathrm{~N} \mathrm{NH}_{4} \mathrm{~A}_{c}$ solution. The effluent was then analyzed in a Kjeldahl flask for ammonium content. The difference in $\mathrm{NH}_{3}$ concentration corresponding to the boiled and unboiled core was used to estimate the $Q_{v}$ of the core. The results of the experimental data obtained on some core samples are shown in Table IV. 